Bot. GAZ. 143(4) :491-497. 1982.

(C) 1982 by The University of Chicago. All rights reserved.

0006-8071/82/4304-0017\$02.00

\title{
VARIABILITY IN CRASSULACEAN ACID METABOLISM: A SURVEY OF NORTH CAROLINA SUCCULENT SPECIES
}

\author{
CRAIG E. MARTIN, ${ }^{1 *}$ ANNE E. LUBBERS, ${ }^{*}$ AND JAMES A. TEERI $\dagger$ \\ *Department of Botany, Duke University, Durham, North Carolina 27706; and +Committee on \\ Evolutionary Biology, University of Chicago, Chicago, Illinois 60637
}

\begin{abstract}
The correlation between succulence and Crassulacean acid metabolism (CAM) was investigated in 28 succulent species growing in various habitats throughout North Carolina. Three species $(O$ puntia compressa, Agave virginica, and Tillandsia usneoides) exhibited diurnal fluctuations in tissue titratable acidity, nighttime uptake of ${ }^{14} \mathrm{CO}_{2}$, and a high carbon isotope ratio $\left({ }^{13} \mathrm{C}\right)$, all indicators of CAM. Seven species displayed one or two characteristics of CAM in situ yet yielded lower $\delta^{13} \mathrm{C}$ values, indicating a partial or total restriction of atmospheric $\mathrm{CO}_{2}$ uptake to the $\mathrm{C}_{3}$ photosynthetic system: Yucca gloriosa, Sesuvium maritimum, Talinum teretifolium, Diamorpha smallii, Sedum pusillum, Sedum nevii, and Sedum telephioides. Several of these species were apparently capable of utilizing the CAM pathway to fix internal respiratory $\mathrm{CO}_{2}$. The results emphasize that one photosynthetic pathway does not characterize all succulents in North Carolina.
\end{abstract}

\section{Introduction}

The relationship between succulence and Crassulacean acid metabolism (CAM) was questioned by KLUGE and TING (1978). With the discovery of CAM in nonsucculent epiphytic bromeliads, such as Tillandsia usneoides (CoutinHo 1969), it was clear that at least some epiphytic CAM plants might not be succulent. It is also possible that, in at least some plant families, there exist terrestrial species capable of CAM which do not have succulent photosynthetic organs (RAO, Swamy, and DAS 1979; TEeri, TONSOR, and TuRner 1981).

To examine the relationship between CAM and succulence, this study was designed to test for the presence of CAM in as many succulents as possible, using plants growing in various habitats in North Carolina. Few species of CAM plants have been reported from the mesic southeastern United States, the most extensively studied species being $T$. usneoides (Martin, Christensen, and Strain 1981; Martin and Siedow 1981; Martin 1982). The only other plants in the southeastern United States reported to be CAM are Opuntia humifusa (BENDER [1971]; probably the same species as $O$. compressa in this study), Sedum telephioides (Mathur, NataRELLA, and VINES 1978), and Yucca filamentosa (SzAREK and Ting [1977]; but see Results and discussion below).

\section{Material and methods}

The criteria for including a species as a succulent were broadly defined to include a maximum number of species. Any species described by RADFORD,

\footnotetext{
${ }^{1}$ Current address and address for correspondence and reprints: Department of Botany, University of Kansas, Lawrence, Kansas 66045.

Manuscript received January 1982; revised manuscript received May 1982.
}

AhLes, and BeLL (1968) as having succulent, fleshy, or thick leaves or photosynthetic stems was included in the study. In addition, several nonsucculent species of genera previously reported to have CAM were sampled, e.g., Yucca and Tillandsia. Only species growing in the state of North Carolina (one study site was located in South Carolina near the North Carolina border) were included in the study (species, habitat types, sites, and sampling dates in table 1).

For calculations of ${ }^{14} \mathrm{CO}_{2}$ uptake rates, photosynthetic organs-either detached shoots, leaves, or portions of leaves (stems in Opuntia compressa) were placed in a Plexiglas chamber $(70 \mathrm{ml}$ vol) and exposed to ${ }^{14} \mathrm{CO}_{2}\left(22 \mu \mathrm{Ci} \cdot\right.$ liter $\left.^{-1}\right)$ in air $(315 \mu \mathrm{l}$. liter ${ }^{-1} \mathrm{CO}_{2}$ ) for $1 \mathrm{~min}$ at a flow rate of $500 \mathrm{ml} \cdot \mathrm{min}^{-1}$. Plants (three replicates per species) were sampled once during midday and once near midnight. After exposure, plant parts were immediately placed in vials at dry-ice temperature $(-78.5 \mathrm{C})$ and subsequently oven-dried ( $65 \mathrm{C})$, cooled in a desiccator, and weighed. They were oxidized with perchloric acid and $\mathrm{H}_{2} \mathrm{O}_{2}$ at $45 \mathrm{C}$ for $12 \mathrm{~h}$. A scintillation cocktail of ethylene glycol monoethyl ether and toluenePPO (2,5-diphenyloxazole) was added after cooling, and the samples were counted in a Beckman LS-250 liquid scintillation counter. Further details of the ${ }^{14} \mathrm{CO}_{2}$-exposure, oxidation, and counting techniques are presented in MARTIN et al. (1981).

For subsequent determination of tissue titratable acidity, leaves or whole plants (five replicates per species) were collected, placed in plastic bags, and immediately frozen on dry ice. In the laboratory, the plant material was ground in distilled water with a mortar and pestle, vacuum filtered, and titrated to $\mathrm{pH} 7.0$ with $0.01 \mathrm{~N} \mathrm{NaOH}$. The filtered material was dried at $65 \mathrm{C}$, cooled in a desiccator, and weighed. Further details of this technique are described in MarTIN et al. (1981). 
Simultaneous with sampling for ${ }^{14} \mathrm{CO}_{2}$ uptake rates and titratable acidity fluctuations, samples of mature photosynthetic tissue were collected and dried $(65 \mathrm{C})$ for mass spectrometric determinations of $\delta^{13} \mathrm{C}$ values, expressed relative to the PDB standard (TEERI 1981). The $\delta^{13} \mathrm{C}$ values for each species (tables 2-6) are means of two determinations; the difference between the replicates was always less than $1.9 \%$.

Voucher specimens were collected and deposited in the Duke University Herbarium.

\section{Results and discussion}

None of the salt marsh succulent species exhibited nighttime ${ }^{14} \mathrm{CO}_{2}$ fixation (table 2). A significant nocturnal increase in tissue titratable acidity was found only in Sesuvium maritimum and may indicate nighttime fixation of respiratory $\mathrm{CO}_{2}$. Fluctuations in tissue acidity without accompanying atmospheric $\mathrm{CO}_{2}$ fixation were also measured in Opuntia basilaris (SZAREK and TING 1974) and several other succulent species (HANSCOM and TING 1978).

The $\delta^{13} \mathrm{C}$ value integrates the lifetime photosynthetic history of a plant or plant part. Thus, the tissue from a $\mathrm{C}_{4}$ plant will yield a carbon isotope ratio of ca. $-13 \%$, that of a $\mathrm{C}_{3}$ plant about $-27 \%$, while that from a CAM plant can vary between these values, depending on what proportion of time the $\mathrm{C}_{3}$ and $\mathrm{C}_{4}$ carboxylating enzymes were functioning in the uptake of atmospheric $\mathrm{CO}_{2}$ throughout the life of the plant (BLACK 1976).

The seven salt marsh species yielded $\delta^{13} \mathrm{C}$ values characteristic of $\mathrm{C}_{3}$ plants (table 2). Based on these data, it appears highly unlikely that any of the salt marsh succulents examined here take up atmospheric $\mathrm{CO}_{2}$ via the CAM pathway. Several of these species were examined previously. Atriplex patula is a $\mathrm{C}_{3}$ species (BJöRkMAN 1973). Although dark ${ }^{14} \mathrm{CO}_{2}$ uptake was reported in Salicornia europaea, S. virginica, and Borrichia frutescens (WEBB and BuRLEY 1965),

TABLE 1

SPECIES, STUDY SITES, AND SAMPLING DATES FOR THE SUCCULENT PLANTS EXAMINED

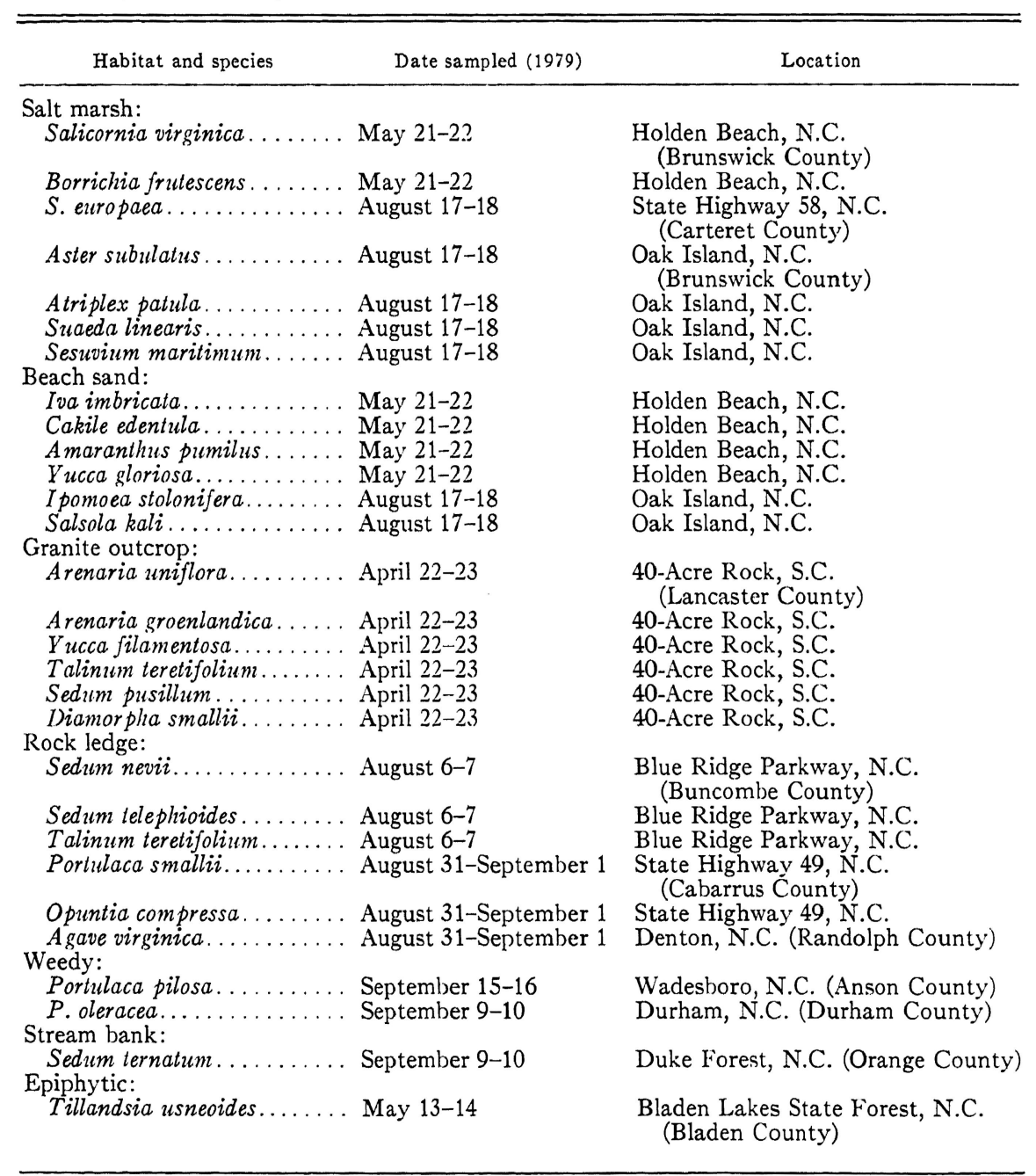


this study and those of WelkIE and CALDwell (1970), ANTLFInger and DunN (1979), and KuRAмото and BREST (1979) indicate that these are $C_{3}$ species. While many species of Suaeda are reportedly $\mathrm{C}_{4}$ plants (Downton 1975), S. linearis lacks Kranz anatomy (WELKIE and CALDWELL 1970), and the $\delta^{13} \mathrm{C}$ value measured for this species in this study $(-25 \%$; table 2$)$ indicates the $C_{3}$ photosynthetic pathway. This species, therefore, also appears to be $\mathrm{C}_{3}$.

Of the seven beach sand species examined, only Yucca gloriosa exhibited significantly higher levels of tissue acidity at sunrise than at sunset (table 3 ). This occurred without a concomitant nocturnal uptake of ${ }^{14} \mathrm{CO}_{2}$, again suggesting a nocturnal fixation of respiratory $\mathrm{CO}_{2}$, as in $S$. maritimum. The carbon isotope ratio $(-22 \%)$ of $Y$. gloriosa is intermediate between typical $\mathrm{C}_{3}$ and $\mathrm{C}_{4}$ values and may indicate an ability to assimilate atmospheric $\mathrm{CO}_{2}$ both at night and during the day. CAM has been found in other Yucca species (Mooney, Troughton, and Berry 1974; Cockburn, Ting, and Sternberg
1979) though not in all, e.g., $Y$. filamentosa (BENDER 1971; this study).

The lack of a significant difference in tissue acidity at sunrise and sunset and the absence of substantial nocturnal ${ }^{14} \mathrm{CO}_{2}$ uptake indicate that the remaining beach sand species were not utilizing the CAM pathway when sampled (table 3 ). The high $\delta^{13} \mathrm{C}$ value of Salsola kali $(-11 \%)$ is typical of a $\mathrm{C}_{4}$ species, and previous studies have confirmed this species to be $\mathrm{C}_{4}$ (TREgunNa and Downton 1967; Welkie and Caldwell 1970). All Amaranthus species examined thus far are $\mathrm{C}_{4}$ (WeLKIE and Caldwell 1970; Downton 1975), and A. pumilus appears to be no exception. Iva imbricata, Cakile edentula, and Ipomoea stolonifera exhibit characteristics typical of $\mathrm{C}_{3}$ plants; there are no known reports of $\mathrm{C}_{4}$ or $\mathrm{CAM}$ in these three genera. Low rates of nighttime ${ }^{14} \mathrm{CO}_{2}$ uptake were found in $A$. pumilus and $C$. edentula and were significantly different from zero ( $95 \%$ confidence intervals did not include zero). Further work is required before these nocturnal $\mathrm{CO}_{2}$ uptake rates can be attributed

TABLE 2

TisSUE TITRATABLE ACIDITIES, ${ }^{14} \mathrm{CO}_{2}$ UPTAKE RATES, AND $\delta^{13} \mathrm{C}$ VALUES FOR SALT MARSH SUCCULENT SPECIES

\begin{tabular}{|c|c|c|c|c|c|c|c|}
\hline \multirow[b]{2}{*}{ SPECIES } & \multicolumn{3}{|c|}{$\begin{array}{c}\text { MEAN } \pm \text { SD } \\
\text { IITRATABLE ACIDITY } \\
\left(\mu \text { eq } \cdot \mathrm{g} \mathrm{DW}^{-1}\right)\end{array}$} & \multicolumn{3}{|c|}{$\begin{array}{c}\text { MEAN } \pm \text { SD } \\
{ }^{14} \mathrm{CO}_{2} \text { UPTAKE RATE } \\
\left(\mathrm{mg} \mathrm{CO}_{2} \cdot \mathrm{h}^{-1} \cdot \mathrm{g} \mathrm{DW}^{-1}\right)\end{array}$} & \multirow[b]{2}{*}{$\delta^{13} \mathrm{C}(\%)$} \\
\hline & Sunrise & Sunset & $\begin{array}{l}\text { Signifi- } \\
\text { cance }^{n}\end{array}$ & Night & Day & $\begin{array}{l}\text { Signifi- } \\
\text { canceb }^{b}\end{array}$ & \\
\hline 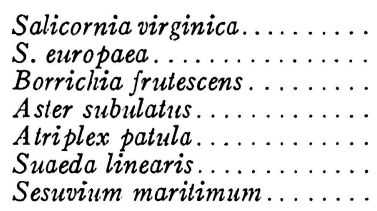 & $\begin{array}{l}36 \pm 7 \\
65 \pm 35 \\
37 \pm 15 \\
42 \pm 16 \\
52 \pm 15 \\
94 \pm 22 \\
50 \pm 4\end{array}$ & $\begin{array}{l}81 \pm 40 \\
49 \pm 15 \\
34 \pm 12 \\
33 \pm 8 \\
39 \pm 21 \\
79 \pm 39 \\
21 \pm 13\end{array}$ & $\begin{array}{l}\text { NS } \\
\text { NS } \\
\text { NS } \\
\text { NS } \\
\text { NS } \\
\text { NS } \\
* *\end{array}$ & $\begin{array}{l}.0 \pm .0 \\
.0 \pm .0 \\
.0 \pm .0 \\
.0 \pm .0 \\
.0 \pm .0 \\
.0 \pm .0 \\
.0 \pm .0\end{array}$ & $\begin{array}{r}16.1 \pm 5.9 \\
35.4 \pm 4.0 \\
26.5 \pm 5.6 \\
6.0 \pm 4.0 \\
6.3 \pm .7 \\
16.2 \pm 4.7 \\
8.8 \pm 2.2\end{array}$ & $\begin{array}{l}* * * \\
* * \\
* \\
\text { NS } \\
* * \\
* \\
*\end{array}$ & $\begin{array}{l}-26 \\
-27 \\
-27 \\
-26 \\
-25 \\
-25 \\
-26\end{array}$ \\
\hline
\end{tabular}

- Levels of significance indicate results of $t$-test (or modified $t^{\prime}$-test in cases of heteroscedasticity; SoKaL and RoHLF [1969]) of the differences \$ Levels of significance indicate results of $t$-test (or modified $t$-test in cases of heteroscedasticity; SoKAl and RoHLF
between mean sunrise acidity and mean sunset acidity. NS $=$ not significant. $*=P<.05, * *=P<.01, * * *=P<.001$. No. $=5$.

b Levels of significance for same tests of the differences between night and day ${ }^{14} \mathrm{CO}_{2}$ uptake rates. No. $=3$.

TABLE 3

Tissue TITRATABLE ACIDITIES, ${ }^{14} \mathrm{CO}_{2}$ UPTAKE RATES, AND $\delta^{13} \mathrm{C}$ VALUES FOR BEACH SAND SUCCULENT SPECIES

\begin{tabular}{|c|c|c|c|c|c|c|c|}
\hline \multirow[b]{2}{*}{ Species } & \multicolumn{3}{|c|}{$\begin{array}{c}\text { MEAN } \pm \text { SD } \\
\text { TITRATABLE ACIDITY } \\
\left(\mu \text { eq } \cdot \mathrm{g} \mathrm{DW}^{-1}\right)\end{array}$} & \multicolumn{3}{|c|}{$\begin{array}{c}\text { MEAN } \pm \text { SD } \\
{ }^{14} \mathrm{CO}_{2} \text { UPTAKE RATE } \\
\left(\mathrm{mg} \mathrm{CO}_{2} \cdot \mathrm{h}^{-1} \cdot \mathrm{g} \mathrm{DW}^{-1}\right)\end{array}$} & \multirow[b]{2}{*}{$\delta^{13} \mathrm{C}(\%)$} \\
\hline & Sunrise & Sunset & $\begin{array}{l}\text { Signifi- } \\
\text { cance }\end{array}$ & Night & Day & $\begin{array}{l}\text { Signifi- } \\
\text { cance }\end{array}$ & \\
\hline 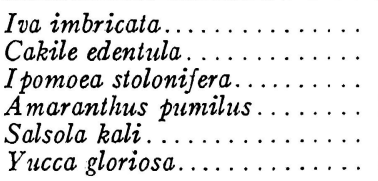 & $\begin{array}{r}55 \pm 2 \\
80 \pm 3 \\
56 \pm \\
136 \pm 9 \\
20 \pm 1 \\
331 \pm 13\end{array}$ & $\begin{array}{r}31 \pm 12 \\
115 \pm 38 \\
49 \pm 17 \\
111 \pm 51 \\
56 \pm 38 \\
123 \pm 24\end{array}$ & $\begin{array}{l}\text { NS } \\
\text { NS } \\
\text { NS } \\
\text { NS } \\
\text { NS } \\
*\end{array}$ & $\begin{array}{l}0 \pm .0 \\
.1 \pm .0 \\
.0 \pm .0 \\
.2 \pm .1 \\
.0 \pm .0 \\
.0 \pm .0\end{array}$ & $\begin{array}{r}62.0 \pm 4.7 \\
55.5 \pm 21.4 \\
7.8 \pm 5.9 \\
20.8 \pm 2.9 \\
3.5 \pm 2.6 \\
6.2 \pm 2.0\end{array}$ & $\begin{array}{l}* * \\
* \\
\text { NS } \\
* * \\
\text { NS } \\
*\end{array}$ & $\begin{array}{l}-27 \\
-29 \\
-27 \\
-13 \\
-11 \\
-22\end{array}$ \\
\hline
\end{tabular}

Note.-Levels of significance determined as in table 2. 
to enzymatic fixation or to contamination of the cut leaf surfaces.

Among the six succulent species found on granite outcrops, the two Arenaria species and $Y$. filamentosa exhibited no nocturnal uptake of ${ }^{14} \mathrm{CO}_{2}$, no difference in titratable acidity at sunrise or sunset, and low, $\mathrm{C}_{3}$-like $\delta^{13} \mathrm{C}$ values $(-26 \% 0$ and $-28 \%$; table 4$)$. It appears that these species were functioning as $\mathrm{C}_{3}$ plants. Talinum teretifolium exhibited rates of nighttime ${ }^{14} \mathrm{CO}_{2}$ uptake not significantly different from zero and much lower than daytime rates; yet the tissue acidity at sunrise was significantly higher than that at sunset (table 4). Conversely, Sedum pusillum exhibited a low but significant (relative to zero) rate of nocturnal ${ }^{14} \mathrm{CO}_{2}$ uptake, but no significant fluctuation in tissue acid content. Though CAM has been reported in many species of Sedum (Szarek and TING 1977), S. pusillum may have some ability to utilize the CAM photosynthetic pathway, but its carbon isotope ratio $(-26 \%$ ) indicates that only the $\mathrm{C}_{3}$ pathway functions in the fixation of atmospheric $\mathrm{CO}_{2}$. A similar $\mathrm{C}_{3}$-like $\delta^{13} \mathrm{C}$ value was found in $T$. teretifolium in spite of the nocturnal accumulation of acid. These results indicate the possible utilization of CAM for limited nighttime uptake of atmospheric $\mathrm{CO}_{2}$ in $S$. pusillum and for nighttime uptake of internal, respiratory $\mathrm{CO}_{2}$ in $T$. teretifolium. Fluctuations in titratable acidity in $T$. guadalupense were reported by KLUGE and Ting (1978).

Diamorpha smallii displayed nighttime ${ }^{14} \mathrm{CO}_{2}$ uptake rates that were low but significantly higher than daytime rates, and tissue acidity at sunrise was significantly higher than that at sunset (table 4). In spite of these indications of in situ CAM, the carbon isotope ratio $(-28 \%)$ suggests that the majority of carbon fixed during the life of the plant was via the $\mathrm{C}_{3}$ carboxylation pathway. Diamorpha smallii seedlings grow in vernal pools on granite outcrops during the mesic spring (McVAUGH 1943). These pools evaporate by late spring or early summer, exposing the plant to potentially great water stress in the shallow, sandy soil. During this time, switching from the $\mathrm{C}_{3}$ to the CAM pathway could potentially result in the conservation of water while the plants remained metabolically active (KLUGE and TING 1978). A similar switch in photosynthetic pathways upon increasing water stress also was observed in annual halophytic Mesembryanthemum species (WINTER et al. 1978; Winter and Troughton 1978).

Several succulent species that grow on rock ledges throughout North Carolina exhibited a variety of ecophysiological traits (table 5). As are numerous other Portulaca species (Downton 1975), $P$. smallii appears to be a $\mathrm{C}_{4}$ plant. There was no nighttime ${ }^{14} \mathrm{CO}_{2}$ uptake, no difference in tissue acidity at sunrise relative to sunset, and a high $\delta^{13} \mathrm{C}$ value $(-13 \%)$. There were several indications of CAM in Opuntia compressa: higher, though not significantly so, rates of nocturnal ${ }^{14} \mathrm{CO}_{2}$ uptake relative to the daytime rate (nighttime rates were significantly different from zero; daytime rates were not), significantly higher tissue acidity at sunrise than at sunset, and a high $\delta^{13} \mathrm{C}$ value characteristic of an obligate CAM plant $(-12 \%)$. Several other studies support these findings of CAM in $O$. compressa (CONDE and KRAMER [1975]; KoCH and KENNEDY [1980b], who reported O. humifusa as a CAM plant; this species is synonymous with $O$. compressa according to RADFORD et al. [1968]).

Although many desert Agave species are CAM plants (SZAREK and TING 1977), no reports of the photosynthetic pathway in $A$. virginica could be found. This may be attributable to the relative scarcity of the plant, at least in North Carolina. A large, significant difference between tissue acid content at sunrise and sunset, as well as low levels of nighttime ${ }^{14} \mathrm{CO}_{2}$ uptake (significantly different from zero), indicates CAM in this species (table 5). The $\delta^{13} \mathrm{C}$ value $(-16 \%)$ also supports these indications of CAM in $A$. virginica.

Although Sedum nevii exhibited no nocturnal ${ }^{14} \mathrm{CO}_{2}$ uptake and yielded a $\mathrm{C}_{3}$-like $\delta^{13} \mathrm{C}$ value

TABLE 4

TISSUE TITRATABLE ACIDITIES, ${ }^{14} \mathrm{CO}_{2}$ UPTAKE RATES, AND $\delta^{13} \mathrm{C}$ VALUES FOR GRANITE OUTCROP SUCCULENT SPECIES

\begin{tabular}{|c|c|c|c|c|c|c|c|}
\hline \multirow[b]{2}{*}{ SpECIES } & \multicolumn{3}{|c|}{$\begin{array}{c}\text { MEAN } \pm \text { SD } \\
\text { IITRATABLE ACIDITY } \\
\left(\mu \text { eq } \cdot \mathrm{g} \mathrm{DW}^{-1}\right)\end{array}$} & \multicolumn{3}{|c|}{$\begin{array}{c}\mathrm{M}_{\mathrm{EAN}} \pm \mathrm{SD} \\
{ }^{14} \mathrm{CO}_{2} \mathrm{UPTAKE}_{\mathrm{RATE}} \\
\left(\mathrm{mg} \mathrm{CO}_{2} \cdot \mathrm{h}^{-1} \cdot \mathrm{g} \mathrm{DW}^{-1}\right)\end{array}$} & \multirow[b]{2}{*}{${ }^{13} \mathrm{C}(\%)$} \\
\hline & Sunrise & Sunset & $\begin{array}{l}\text { Signifi- } \\
\text { cance }\end{array}$ & Night & Day & $\begin{array}{l}\text { Signifi- } \\
\text { cance }\end{array}$ & \\
\hline $\begin{array}{l}\text { A renaria uniflora.... } \\
\text { A. groenlandica...... } \\
\text { Yucca filamentosa.... } \\
\text { Talinum teretifolium. } \\
\text { Sedum pusillum..... } \\
\text { Diamorpha smallii... }\end{array}$ & $\begin{array}{r}108 \pm 21 \\
97 \pm 26 \\
85 \pm 36 \\
798 \pm 173 \\
211 \pm 49 \\
454 \pm 45\end{array}$ & $\begin{array}{r}129 \pm 39 \\
120 \pm 21 \\
70 \pm 38 \\
280 \pm 65 \\
177 \pm 20 \\
305 \pm 52\end{array}$ & $\begin{array}{l}\text { NS } \\
\text { NS } \\
\text { NS } \\
* * * \\
\text { NS } \\
* *\end{array}$ & $\begin{array}{l}.0 \pm .0 \\
.0 \pm .0 \\
.0 \pm .0 \\
.1 \pm .1 \\
.1 \pm .0 \\
.2 \pm .0\end{array}$ & $\begin{array}{l}3.3 \pm 1.4 \\
4.4 \pm .8 \\
2.9 \pm 1.4 \\
.8 \pm .8 \\
.9 \pm .7 \\
.0 \pm .0\end{array}$ & $\begin{array}{l}\text { NS } \\
* \\
\text { NS } \\
\text { NS } \\
\text { NS } \\
* *\end{array}$ & $\begin{array}{l}-28 \\
-28 \\
-26 \\
-27 \\
-26 \\
-28\end{array}$ \\
\hline
\end{tabular}

Note.-Levels of significance determined as in table 2. 
$(-27 \%)$, tissue titratable acidity at sunrise was significantly higher than at sunset (table 5). As with several species above, these findings may indicate refixation of nocturnal respiratory $\mathrm{CO}_{2}$. Sedum telephioides, reported as a CAM plant (SzAREK and TING 1977), exhibited characteristics typical of CAM plants: a significantly greater rate of nocturnal ${ }^{14} \mathrm{CO}_{2}$ uptake relative to daytime (and significantly greater than zero), and a higher tissue acid content at sunrise than at sunset. On the other hand, its intermediate $\delta^{13} \mathrm{C}$ value $(-23 \%$ ) suggests the importance of the $\mathrm{C}_{3}$ pathway to this apparently facultative CAM plant.

In addition to the populations at the granite outcrop site, $T$. teretifolium was also found on rock ledges in the mountains of North Carolina. Similar to the granite outcrop plants, the rock ledge $T$. teretifolium exhibited significantly greater tissue acidity at sunrise than at sunset (table 5). However, zero nocturnal and daytime ${ }^{14} \mathrm{CO}_{2}$ uptake rates were found in the rock ledge plants. The nighttime increase in tissue acidity may be attributed to refixation of respiratory $\mathrm{CO}_{2}$. Similar $\mathrm{C}_{3}$-like carbon isotope ratios were found in both populations of $T$. teretifolium, emphasizing the predominance of the $\mathrm{C}_{3}$ pathway for fixing atmospheric $\mathrm{CO}_{2}$ in this species, in spite of the ability to utilize the CAM pathway.

The four remaining succulent species examined for the presence of CAM in this study were found in several different habitats: $P$. pilosa in a sandy, disturbed area, $P$. oleracea in urban sidewalk crevices, Sedum ternatum on a stream bank in an oak-hickory forest, and Tillandsia usneoides, epiphytic on an oak tree. Both Portulaca species have been reported as $C_{4}$ species (Downton 1975), and the ability to utilize the CAM pathway was reported for $P$. oleracea (KocH and KENNEDy 1980a). In this study, neither species exhibited nighttime ${ }^{14} \mathrm{CO}_{2}$ uptake, no differences between tissue acid content at sunrise and sunset were found, and the $\delta^{13} \mathrm{C}$ values were $\mathrm{C}_{4}$-like $(-11 \% 0,-13 \%$; table 6$)$. Sedum ternatum exhibited characteristics typical of $\mathrm{C}_{3}$ species: no nighttime ${ }^{14} \mathrm{CO}_{2}$ uptake, no differences in tissue acid content at sunrise and sunset, and a $\mathrm{C}_{3}$-like $\delta^{13} \mathrm{C}$ value $(-30 \%$; table 6$)$. Previous work with $T$. usneoides in North Carolina established the predominance of the CAM pathway in this epiphyte

TABLE 5

Tissue TITRATABLE ACIDITIES, ${ }^{14} \mathrm{CO}_{2}$ UPTAKE RATES, AND $\delta^{13} \mathrm{C}$ VALUES FOR ROCK LEDGE SUCCULENT SPECIES

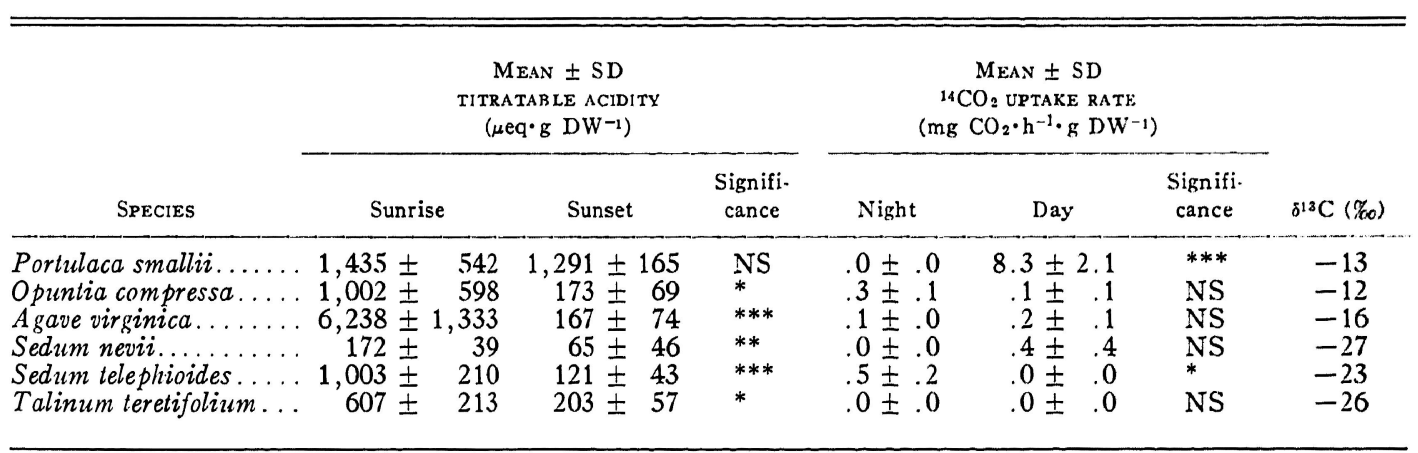

Note.-Levels of significance determined as in table 2.

TABLE 6

TISSUE TITRATABLE ACIDITIES, ${ }^{14} \mathrm{CO}_{2}$ UPTAKE RATES, AND $\delta^{13} \mathrm{C}$ VALUES FOR WEEDY, STREAMBANK, AND EPIPHYTIC SUCCULENT SPECIES

\begin{tabular}{|c|c|c|c|c|c|c|c|}
\hline \multirow[b]{2}{*}{ SpECIES } & \multicolumn{3}{|c|}{$\begin{array}{c}\text { MEAN } \pm \text { SD } \\
\text { TITRATABLE ACIDITX } \\
\left(\mu \text { eq. } \mathrm{g} \mathrm{DW}^{-1}\right) \\
\end{array}$} & \multicolumn{3}{|c|}{$\begin{array}{c}\mathrm{M}_{\text {EAN }} \pm \mathrm{SD} \\
{ }^{14} \mathrm{CO}_{2} \mathrm{UPAKE}_{\mathrm{RATE}} \\
\left(\mathrm{mg} \mathrm{CO}_{2} \cdot \mathrm{h}^{-1} \cdot \mathrm{g} \mathrm{DW}^{-1}\right) \\
\end{array}$} & \multirow[b]{2}{*}{$\delta^{13} \mathrm{C}(\%$} \\
\hline & Sunrise & Sunset & $\begin{array}{l}\text { Signifi- } \\
\text { cance }\end{array}$ & Night & Day & $\begin{array}{l}\text { Signifi- } \\
\text { cance }\end{array}$ & \\
\hline $\begin{array}{l}\text { Weedy: } \\
\quad \text { Portulaca pilosa ....... } \\
\quad \text { P. oleracea......... }\end{array}$ & $\begin{array}{l}258 \pm 65 \\
147 \pm 63\end{array}$ & $\begin{array}{l}219 \pm 60 \\
186 \pm 116\end{array}$ & $\begin{array}{l}\text { NS } \\
\text { NS }\end{array}$ & $\begin{array}{l}.0 \pm .0 \\
.0 \pm .0\end{array}$ & $\begin{array}{l}5.5 \pm 2.8 \\
6.1 \pm 1.7\end{array}$ & $\underset{*}{\mathrm{NS}}$ & $\begin{array}{l}-11 \\
-13\end{array}$ \\
\hline $\begin{array}{l}\text { Streambank: } \\
\text { Sedum ternatum....... } \\
\text { Epiphytic: }\end{array}$ & $74 \pm 28$ & $60 \pm 26$ & NS & $.0 \pm .0$ & $1.9 \pm .1$ & $* * *$ & -30 \\
\hline Tillandsia usneoides.... & $500 \pm 137$ & $119 \pm 37$ & $*$ & $.4 \pm .2$ & $.0 \pm .0$ & $* * *$ & -15 \\
\hline
\end{tabular}

Note.-Levels of significance determined as in table 2. 
(Martin et al. 1981; Martin and Siedow 1981). The lack of daytime ${ }^{14} \mathrm{CO}_{2}$ uptake, significantly higher tissue acid content at sunrise than at sunset, and the high $\delta^{13} \mathrm{C}$ value characteristic of the $\mathrm{C}_{4}$ carboxylating enzyme system ( $-15 \%$; table 6$)$ further support the previous findings.

Several methodological problems were unavoidable in a study of this nature. To include as many succulent species as possible, sample sizes were small, often resulting in large but nonsignificant differences between means; environmental conditions were not consistent between sample dates, though most species were sampled after several days of drought; and measurements were made at one point in time only. Therefore, this study cannot preclude the possibility that a species may exhibit CAM behavior at times other than that sampled.

The results of this study emphasize the lack of correlation between CAM and succulence; i.e., the presence of succulence in a plant is not necessarily a good indication of the presence of a functioning
CAM pathway. On the other hand, except for $T$. usneoides and possibly $Y$. gloriosa, all of the CAM and facultative CAM species investigated in this study were succulent.

This study also emphasizes the potential difficulty in attempting to classify species with regard to their photosynthetic pathway. Several species in this study exhibited in situ characteristics of one type of metabolism, yet their carbon isotope discrimination ratio indicated the predominance of another pathway in the initial uptake of atmospheric $\mathrm{CO}_{2}$ throughout the life of the plant.

\section{Acknowledgments}

We thank T. S. TeERI and E. VAN SANTEN for excellent technical assistance, as well as the University of Kansas secretarial staff for typing the manuscript. This research was supported in part by the DeKalb Foundation and NSF grant DEB 8021270 to J. A. TEERI.

\section{LITERATURE CITED}

ANTLFInger, A. E., and E. L. Dunn. 1979. Seasonal patterns of $\mathrm{CO}_{2}$ and water vapor exchange of three salt marsh succulents. Oecologia 43:249-260.

BENDER, M. M. 1971. Variations in the ${ }^{13} \mathrm{C} /{ }^{12} \mathrm{C}$ ratios of plants in relation to the pathway of photosynthetic carbon dioxide fixation. Phytochemistry 10:1239-1244.

BJöRKMAN, O. 1973. Comparative studies on photosynthesis in higher plants. Photophysiology 8:1-63.

BLACK, C. C., JR. 1976. Fractionation of stable carbon isotopes during Crassulacean acid metabolism and the presentation of a unified concept of diurnal $\mathrm{CO}_{2}$ metabolism in CAM plants. Pages 51-73 in C. R. BENEDICT, ed. The fractionation of stable carbon isotopes by plants. Southern Sect. Amer. Soc. Plant Physiol. Symp., New Orleans, Louisiana.

Cockburn, W., I. P. Ting, and L. O. Sternaerg. 1979. Relationships between stomatal behavior and internal carbon dioxide concentration in Crassulacean acid metabolism plants. Plant Physiol. 63:1029-1032.

Conde, L. F., and P. J. KRamer. 1975. The effect of vapor pressure deficit on diffusion resistance in Opuntia compressa. Can. J. Bot. 53 :2923-2926.

Coutinho, L. M. 1969. Novas observaçōes sôbre a occurrência do "Efeito de De Saussure" e suas relações com a suculência, a temperatura folhear e os movimentos estomáticos. Fac. Filosofia Ciênc. Letras Univ. São Paulo (Brazil) 24(331):79-102.

Downton, W. J. S. 1975. The occurrence of $\mathrm{C}_{4}$ photosynthesis among plants. Photosynthetica 9:96-105.

Hanscom, Z., III, and I. P. Ting. 1978. Responses of succulents to plant water stress. Plant Physiol. 61:327-330.

KLUGE, M., and I. P. TING. 1978. Crassulacean acid metabolism: analysis of an ecological adaptation. Springer, Berlin.

KOCH, K. E., and R. A. KeNNEDY. 1980a. Characteristics of Crassulacean acid metabolism in the succulent $\mathrm{C}_{4}$ dicot, Portulaca oleracea L. Plant Physiol. 65:193-197.

- $1980 b$. Effects of seasonal changes in the midwest on Crassulacean acid metabolism (CAM) in Opuntia humifusa Raf. Oecologia 45:390-395.

Kuramoto, R. T., and D. E. Brest. 1979. Physiological response to salinity by four salt marsh plants. Bot. GAZ. 140:295-298.
McVaugh, R. 1943. The vegetation of the granitic flat-rocks of the southeastern United States. Ecol. Monogr. 13:121166.

MarTin, C. E. 1982. Translocation of nocturnally-fixed ${ }^{14} \mathrm{C}$ in the Crassulacean acid metabolism epiphyte Tillandsia usneoides L. Bot. GAZ. 143:1-4.

Martin, C. E., N. L. Christensen, and B. R. Strain. 1981. Seasonal patterns of growth, tissue acid fluctuations, and ${ }^{14} \mathrm{CO}_{2}$ uptake in the Crassulacean acid metabolism epiphyte Tillandsia usneoides L. (Spanish moss). Oecologia 49:322328.

Martin, C. E., and J. N. Siedow. 1981. Crassulacean acid metabolism in the epiphyte Tillandsia usneoides L. (Spanish moss). Responses of $\mathrm{CO}_{2}$ exchange to controlled environmental conditions. Plant Physiol. 68:335-339.

Mathur, D. D., N. J. Natarella, and H. M. Vines. 1978. Elemental analyses of Crassulacean acid metabolism plant tissue. Comm. Soil Sci. Plant Anal. 9:127-139.

Mooney, H., J. H. Troughton, and J. A. Berry. 1974. Arid climates and photosynthetic systems. Carnegie Inst. Washington Yearbook 73:793-805.

RAdFord, A. E., H. E. AhLes, and C. R. BeLl. 1968. Manual of the vascular flora of the Carolinas. University of North Carolina Press, Chapel Hill.

RaO, I. M., P. M. Swamy, and V. S. R. Das. 1979. Some characteristics of Crassulacean acid metabolism in five nonsucculent scrub species under natural semiarid conditions. Z. Pflanzenphysiol. 94:201-210.

SokAl, R. R., and F. J. RohlF. 1969. Biometry. W. H. Freeman, San Francisco.

Szarek, S. R., and I. P. Ting. 1974. Seasonal patterns of acid metabolism and gas exchange in Opuntia basilaris. Plant Physiol. 54:76-81.

- 1977. Review: the occurrence of Crassulacean acid metabolism among plants. Photosynthetica 11:330-342.

TeERI, J. A. 1981. Stable carbon isotope analysis of mosses and lichens growing in xeric and moist habitats. Bryologist $84: 82-84$.

Teeri, J. A., S. J. Tonsor, and M. Turner. 1981. Leaf thickness and carbon isotope composition in the Crassulaceae. Oecologia $50: 367-369$. 
Tregunna, E. B., and J. Downton. 1967. Carbon dioxide compensation in members of the Amaranthaceae and some related families. Can. J. Bot. 45:2385-2387.

WEBB, K. L., and J. W. A. BurLEy. 1965. Dark fixation of $\mathrm{C}^{14} \mathrm{O}_{2}$ by obligate and facultative salt marsh halophytes. Can. J. Bot. 43:281-285.

Welkie, G. W., and M. Caldwell. 1970. Leaf anatomy of species in some dicotyledon families as related to the $C_{3}$ and
$\mathrm{C}_{4}$ pathways of carbon fixation. Can. J. Bot. 48:2135-2146. Winter, K., U. LÜttge, E. Winter, and J. H. Troughton. 1978. Seasonal shift from $C_{3}$ photosynthesis to Crassulacean acid metabolism in Mesembryanthemum crystallinum growing in its natural environment. Oecologia 34:225-237.

Winter, K., and J. H. Trovghton. 1978. Carbon assimilation pathways in Mesembryanthemum nodiflorum L. under natural conditions. Z. Pflanzenphysiol. 88:153-162. 